\title{
Si-Ho Tchou: life of a legend from physiology to psychology
}

\author{
Wei Chen ${ }^{1,2 \bowtie}, X_{\text {C Chen }}^{3}$, Shengjun Wen ${ }^{4}$ \\ ${ }^{1}$ Department of Psychology, Shaoxing University, Shaoxing 312000, China \\ 2 Department of Psychology, The Education University of Hong Kong, Hongkong, China \\ ${ }^{3}$ College of Humanities, Shanghai University of Finance and Economics, Shanghai 200433, China \\ ${ }^{4}$ Department of Cognitive Neurology, Hertie Institute for Clinical Brain Research, University of Tübingen, 72076 Tübingen, \\ Germany \\ $\square$ Correspondence: anti-monist@163.com (W. Chen)
}

\begin{abstract}
Why do the bees renounce sleep, the joys of honey, love, and divine leisure? Why do they get so much pain and effort, and where does such a decisiveness come from? So the sex they are dying for must deserve this sacrifice, it must be more beautiful, happier, and do something they can not do?

Maurice Maeterlinck, Das Leben der Bienen, 1901
\end{abstract}

Dr. Si-Ho Tchou (朱锡侯, 1914-2000) was born in the northeast part of Jilin Province, although his ancestry can be traced to Shaoxing, Zhejiang Province (Fig. 1). Dr. Tchou graduated from the L'Institut Franco-Chinois de Lyon (IFCL) in 1937 and was selected to continue his studies in France. Dr. Tchou spent eight years in France, where he first obtained his $\mathrm{PhD}$ in physiology from the University of Lyon and then received his $\mathrm{PhD}$ in psychology from the University of Paris. Dr. Tchou returned back to China in 1945 and was appointed as a professor in physiology at Yunnan University School of Medicine. Meantime, he was also appointed as a professor in psychology and aesthetics at Yunnan University, School of Humanities and Law. In 1980, he became the professor of physiology and psychology at the department of psychology in Hangzhou University. Then he served as a member of the physiological psychology committee in Chinese Psychological Society.

Dr. Tchou has made significant achievements during the eight years' study in France. At the University of Lyon, Dr. Tchou first studied aesthetics and psychology under the guidance of the famous aesthetician and psychologist Prof. Étienne Souriau and received master's degree in Arts (Fig. 2). Then he transferred to Medical School to study under the supervision of a brilliant physiologist Prof. Henri Cardot. He is also the student of Prof. Charle Richet who was the Nobel Laureate in physiology or Medicine in 1913. Both of them are well known for their researches on the body's immune reactions to foreign substances (Stewart, 2012).

During the holidays, Dr. Tchou joined his mentor Prof. Cardot to the marine life station by the Mediterranean Sea, where he conducted researches on animal nerve cells and nerve fibers, spending days and nights recording nerve impulses in a tiny laboratory. At that time, their researches focused on the glandular giant neurons of marine invertebrates like Aplysia, and they had to go daily to the sea to capture Aplysia. Dr. Tchou was responsible to differentiate the glands and giant neurons of Aplysia based to their weight, and the other research project he conducted was to compare the neural discharge rhythms of Aplysia, based on their weight. At the end of 1942, Dr. Tchou was awarded a PhD degree in Science from the University of Lyon for his work on the growth pattern and rhythmic discharge phenomenon of neurons in Aplysia. His findings showed that the glands and giant neurons of Aplysia could be easily identified and sorted out. In addition, he found that the cell size was only a superficial feature of cell differentiation (Tauc, 1966; Ingoglia and Sturman, 1980; Ambron and Kremzner, 1982; Abel and Kandel, 1998).

As early as 1942, Dr. Tchou has studied the giant neurons of Aplysia, and together with Dr. Arvanitaki, published the paper "Laws of the relative individual growth of nerve cells in Aplysia", where they recorded and quantified the number and relative size of individual neurons at different stages (Arvanitaki and Tchou, 1942). Based on this work, French scientists Dr. Tauc (1954) and Dr. Arvanitaki (1955) pioneered researches on single cell recording of giant neurons using microelectrodes. In addition, benefiting from the methods reported by Dr. Tchou, Prof. Kandel's team found that habituation and dishabituation was due to the synaptic potential of gill motor neurons (Pinsker et al., 1970; Kupfermann et al., 1970; Carew and Kandel, 1973; Castellucci and Kandel, 1976; Kandel and Schwartz, 1982; Voronezhskaya and Croll, 2015). 


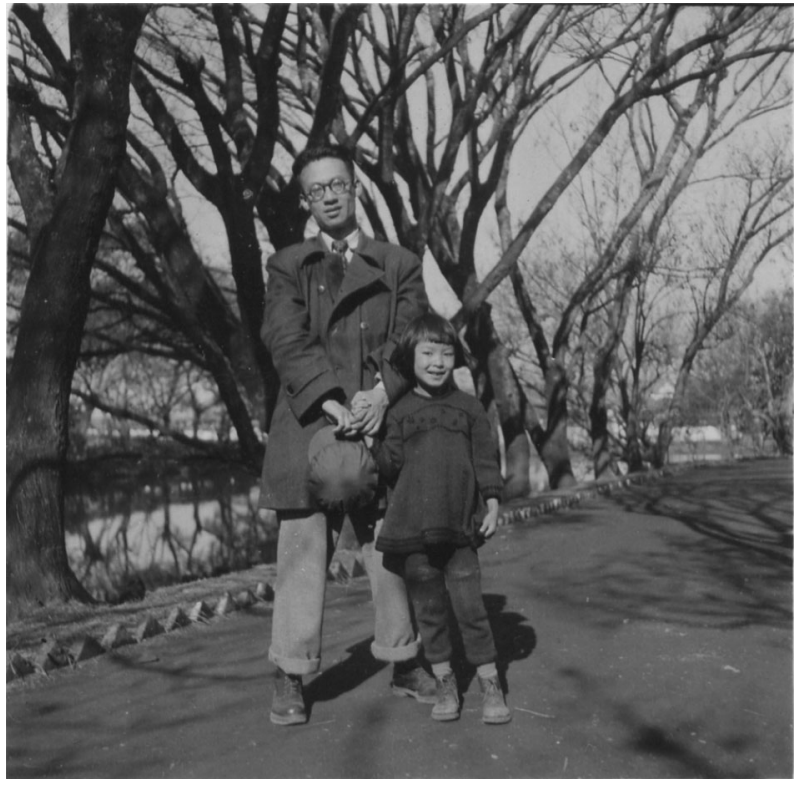

Figure 3. Si-Ho Tchou with his eldest daughter in Yunnan University, circa 1955.

Figure 4. Si-Ho Tchou in the early to the Hangzhou University.

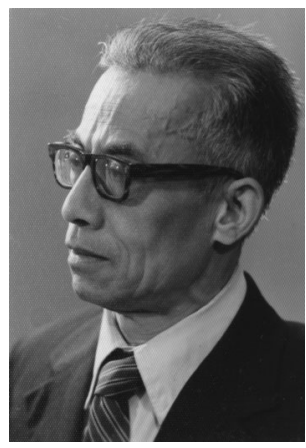

Unfortunately, Dr. Tchou was innocently involved in a political turmoil in 1957. After experiencing major hardships in life, Dr. Tchou went to Hangzhou University (Fig. 4). "To be honest, I am already 66 years old. I really hope to be able to return to psychology in my remaining years and do my bit for education in China... I just want to work... (朱锡侯, 2011, p. 197)". At that time, psychology has been neglected in China for decades and was treated as a pseudoscience of the bourgeoisie. There was an enormous gap with the international community in this research area. Although the setting up of physiological psychology classes has been proposed, there were no references available domestically. Therefore, Dr. Tchou searched through a large number of foreign texts and magazines, excerpted the information that was suitable for the physiological psychology classes and translated some of the basic teaching materials such as Introduction to Physiological Psychology by Allen Schneider and Barry Tarshis; Introduction to Physiological Psychology by Charles Levinthal. On November 20, 1980, the inaugural assembly and symposium of the physiological psychology professional committee of Chinese Psychological Society was held in Nanjing Normal University, and as one of the organizing committee members, the two textbooks translated by Dr. Tchou were also included in the proceedings. Indeed, Dr. Tchou has paved the way for the development of physiological psychology and was certainly the pioneer of physiological psychology. While the teaching conditions were tough, it allowed him to develop a close relationship with his students. He often directed student essays, and discovered a constant relationship between time perception and the adjustment of knowledge and experience (朱琪, 1985).

Dr. Tchou made brilliant achievements in the fields of Western philosophy, aesthetics, physiology and psychology. With his in-depth researches in understanding the mysteries of human brain functions, he made outstanding contributions to the development of physiology and psychology in China. As he once said, "There is a common thread running through my lifetime's learning, that is, to know the mystery of life, to understand people's inner worlds, their psychological activities and psychological lives... It is the logical connection in my journey beginning from philosophy, to psychology, aesthetics, neurophysiology, physiological psychology, and finally, the life sciences (朱锡侯, 2011, p. 210)”.

\section{ACKNOWLEDEGMENTS}

This work was supported by grant 'The National Social Science Foundation (16CZX015)', and we also thank the daughter of Si-Ho Tchou-Xindi Zhou for photo supplies and use.

\section{OPEN ACCESS}

This article is distributed under the terms of the Creative Commons Attribution 4.0 International License (http://creativecommons.org/ licenses/by/4.0/), which permits unrestricted use, distribution, and reproduction in any medium, provided you give appropriate credit to the original author(s) and the source, provide a link to the Creative Commons license, and indicate if changes were made.

\section{REFERENCES}

Abel T, Kandel E (1998) Positive and negative regulatory mechanisms that mediate long-term memory storage. Brain Res Rev 26:360-378

Adams WB, Benson JA (1985) The generation and modulation of endogenous rhythmicity in the Aplysia, bursting pacemaker neurone r15. Prog Biophys Mol Biol 46(1):1-49

Ambron RT, Kremzner LT (1982) Post-translational modification of neuronal proteins: evidence for transglutaminase activity in r2, the giant cholinergic neuron of Aplysia. Proc Natl Acad Sci USA 79(11):3442-3446

Arvanitaki A, Tchou SH (1942) Les Lois de la croissance relative individuelle des cellules nerveuses chez l'Aplysie. Bull D'Histologieet de Tech Microsc 19:244-256 
Bailey CH, Chen M (1988) Long-term sensitization in Aplysia increases the number of presynaptic contacts onto the identified gill motor neuron L7. Proc Natl Acad Sci USA 85(23):9356-9359

Carew TJ, Kandel ER (1973) Acquisition and retention of long-term habituation in Aplysia: correlation of behavioral and cellular processes. Science 182(4117):1158-1160

Castellucci V, Kandel ER (1976) An invertebrate system for the cellular study of habituation and sensitization. In: Tighe TJ, Leaton RN (eds) Habituation: perspectives from child development, animal behavior, and neurophysiology. Erlbaum, Hillsdale, NJ, pp 1-47

Cleary LJ, Baxter DA, Nazif F, Byrne JH (1991) Neural mechanisms underlying sensitization of a defensive reflex in Aplysia. Biol Bull 180(180):252-261

Coggeshall RE, Kandel ER, Kupfermann I, Waziri R (1966) A morphological and functional study on a cluster of identifiable neurosecretory cells in the abdominal ganglion of Aplysia Californica. J Cell Biol 31(2):363-368

Hughes GM (1968) The left and right giant neurons (LGC and RGC) of Aplysia. In: Salánki J (ed) Neurobiology of invertebrates. Springer, Boston, MA, pp 423-441

Hughes GM, Tauc L (1961) The path of the giant cell axons in Aplysiadepilans. Nature 191:404-405

Ingoglia NA, Sturman JA (1980) Axonal transport of putrescine and the polyamines. Neurochem Res 5(8):913-914

Kandel ER, Schwartz JH (1982) Molecular biology of learning: modulation of transmitter release. Science 218(4571):433-443

Kandel ER, Tauc L (1965) Heterosynaptic facilitation in neurones of the abdominal ganglion of Aplysiadepilans. J Physiol 181:1-27

Koester J, Kandel ER (1977) Further identification of neurons in the abdominal ganglion of Aplysia using behavioralcriteria. Brain Res 121(1):1-20
Kupfermann I, Castellucci V, Pinsker H, Kandel E (1970) Neuronal correlates ofhabituation and dishabituation of gill-withdrawal reflex in Aplysia. Science 167(3926):1743-1745

Peretz B, Lukowiak KD (1975) Age-dependent CNS control of the habituating gill withdrawal reflex and of correlated activity in identified neurons in Aplysia. J Comp Physiol 103(1):1-17

Pinsker H, Kupfermann I, Castellucci V, Kandel E (1970) Habituation and dishabituation of the gm-withdrawal reflex in Aplysia. Science 167(3926):1740-1742

Shapiro E, Castellucci VF, Kandel ER (1980) Presynaptic membrane potential affects transmitter release in an identified neuron in aplysia by modulating the $\mathrm{Ca} 2+$ and $\mathrm{K}+$ currents. Proc Natl Acad Sci USA 77(1):629-633

Stewart W (2012) Brain, mind, and medicine: Charles Richet and the origins of physiological psychology. Transaction Publishers, New Brunswick and London

Tauc L (1966) Physiology of the nervous system. In: Wilbur KM, Yonge CM (eds) Physiology of mollusca, vol 2. Academic Press, New York, pp 387-454

Tchou SH (1942) Contribution à l'étude de la physiologie des cellules nerveuses chez l'aplysie. Bosc Frères \& Riou, Lyon

Voronezhskaya EE, Croll RP (2015) Mollusca: Gastropoda. In: Schmidt-Rhaesa A, Harzsch S, Purschke G (eds) Structure and evolution of invertebrate nervous systems. Oxford University Press, Oxford and New York, pp 196-221

朱琪 (1985) 幻嗅过程中知识和经验的调整作用与时间知觉恒常性.心 理科学 6:42-46

朱锡侯 (口述), 朱新地 (整理) (2011)昨夜星辰昨夜风: 八十自述. 北京: 人民文学出版社 